Сегін, Л. В. (2021). Словотвірний потенціал префіксальних дієслів зі значенням «переміщення вгору» в українській і польській мовах (зіставно-типологічний аспект). Studia z Filologii Polskiej i Słowiańskiej, 56, Article 2298. https://doi.org /10.11649/sfps.2298

Sehin, L. V. (2021). Slovotvirnyĭ potentsial prefiksal'nykh diiesliv zi znachenniam "peremishchennia vhoru” v ukraïns'kiı̌ i pol's'kiĭ movakh (zistavno-typolohichnyı̆ aspekt). Studia z Filologii Polskiej i Słowiańskiej, 56, Article 2298. https://doi.org /10.11649/sfps.2298

\author{
Любомир В. Сегін \\ (Національний університет \\ «Києво-Могилянська академія», Київ)
}

\title{
Словотвірний потенціал префіксальних дієслів зі значенням «переміщення вгору» в українській і польській мовах (зіставно-типологічний аспект)
}

На сьогодні в індоєвропейських мовах відомі спроби створення типології словотвірних парадигм (далі - СП) різних ЛСГ дієслів на матеріалі словацької (Buzássyová, 1974) української (Грещук та ін., 2007; Клименко та ін., 1982; Кушлик, 2015 та ін.), російської (Т. С. Морозова, Т. В. Чиканцева; Бразаускене, 1991 та ін.) мов ${ }^{1}$. Проте не може залишатися поза увагою дослідників і зіставно-типологічне вивчення дієслів на рівні словотвору. Ще в 1969 році

1 Структурно-семантичні особливості словотвірних парадигм префіксальних дієслів зі значенням «переміщення вгору» проаналізовано в публікаціях як на матеріалі української (Сегін, 2019), так і польської мови (Сегін, 2020).

This is an Open Access article distributed under the terms of the Creative Commons Attribution 3.0 PL License (creativecommons.org/licenses/by/3.0/pl/), which permits redistribution, commercial and non-commercial, provided that the article is properly cited. (c) The Author(s) 2021.

Publisher: Institute of Slavic Studies, Polish Academy of Sciences

[Wydawca: Instytut Slawistyki Polskiej Akademii Nauk] 
I. І. Ковалик зазначав, що «[...] порівняльному вивченню словотвору споріднених мов приділялося відносно мало уваги [...]» (Ковалик, 1969, с. 4). Ці слова не втратили своєї актуальності. Цікавість до таких досліджень на рівні словотвору зростає, свідченням чого $€$ ціла низка публікацій, присвячених цій проблематиці (Валюх, 2013; Клименко, 1991; Сопоставительное, 1987; Jochym-Kuszlikowa, 1982; Karpiłowska, 2007; Ohnheiser, 2003; Koriakowcewa, 2010 та ін.), які стимулюють проведення зіставних досліджень словотвірних одиниць. Дослідники констатують, що цей аспект словотвору $\epsilon$ одним із пріоритетних напрямків сучасної лінгвістики (Сопоставительное, 1987, с. 4). Як відомо, у типології існують різні думки щодо залучення близькоспоріднених мов. Проте останнім часом усе частіше мовознавці наголошують на тому, що результати зіставлення споріднених мов можуть бути не просто релевантними, але й дуже важливими для типології (Рахилина \& Прокофьева, 2004, с. 60 та ін.).

У теоретичних розробках зіставного словотвору наголошують на тому, що за основу необхідно прийняти семантику: «відправним пунктом зіставного вивчення слов'янського словотвору [...] є смисл» (Земская та ін., 1993, с. 249). Зіставлення на такій основі полягає «в поглибленому пізнанні системно-функціональних закономірностей зіставлюваних феноменів і виявленні на цій основі подібностей і відмінностей між ними, а також деяких загальномовних універсалій» (Нещименко, 1983, с. 31). Водночас перед дослідниками зіставного словотвору слов'янських мов постає важливе завдання з пошуку методу, який гарантуватиме об'єктивне дослідження (Земская та ін., 1993, с. 248). Під час дискусій мовознавці дійшли до висновків, що такий опис повинен спиратися на спільну основу (мову-еталон, tertium comparationis), як таку пропонують різні одиниці (Ковалик, 1969; Сопоставительное, 1987; Ohnheiser, 2003 та ін.). Дериватологи зазначають, що нові перспективи зіставного дослідження словотвору слов'янських мов відкриває використання в ньому комплексної одиниці основоцентричної дериватології - СП, яка «є зручним об’єктом зіставлення, найбільш чітко показує системний характер словотвору» (Бузашшиова, 1987; Земская та ін., 1993, с. 250). Наразі в лінгвістиці на рівні СП проаналізовано словотвірні можливості дієслів у зіставно-типологічному аспекті на матеріалі російської і вірменської (Р. С. Манучарян), російської, польської і чеської (Т. А. Ацаркіна), української, російської і польської (Н. О. Ярошенко), польської і чеської (Malanowska-Statkiewicz, 2017), польської і болгарської (В. Малджиєва), російської і німецької (Т. І. Скоробагата). Спеціального комплексного дослідження словотвірного потенціалу хоча 
6 окремих ЛСГ дієслів сучасних слов'янських мов у зіставно-типологічному зрізі поки що немає, хоча «виявлення і опис словотвірного потенціалу різних класів слів різних частин мови в різних слов'янських мовах $€$ важливим завданням зіставного системного вивчення словотвору і лексики» (Земская та ін., 1993, с. 251).

Мета статті - проаналізувати словотвірні можливості префіксальних дієслів зі значенням «переміщення вгору» української і польської мов у зіставно-типологічному аспекті.

Матеріалом для дослідження слугували девербативи української і польської мов, отримані методом суцільної вибірки з найавторитетніших лексикографічних джерел (ВЗОССУЛ, 2003; ВТССУМ, 2001; СУМГ, 1996; СУМ, 1970-1980; SJPD, 1958-1969; SGSWJO, 2004; WSJP, б.p.). Обсяг вибірки склав 630 одиниць, із яких 139 твірних (укр. - 71; пол. - 68) та 491 похідний (укр. - 180; пол. - 311) дериват в обох мовах.

У нашому дослідженні склад ЛСГ визначаємо на основі аналізу дефініцій слів у тлумачних словниках української і польської мов. Також вважаємо за потрібне зазначити, що в пропонованому дослідженні словотвірного потенціалу дієслів зі значенням «переміщення вгору» предметом аналізу твірної бази виступають лексико-семантичні варіанти лексем. Від префіксальних дієслів зі значенням «переміщення вгору» доконаного виду утворюються дієслова недоконаного виду зазвичай за допомогою формантів -а-, -ува- / -ywa-, -iwa-, напр., укр. підлетіти $\rightarrow$ niдлітати, вивищити $\rightarrow$ вивищувати, пол. podrzисіс́ $\rightarrow$ podrzuсас́, wzlecieć $\rightarrow$ wzlatywać і под., які розглядаємо як тотожні за значенням, але різні за видом і вважаємо їх такими, що виникли шляхом імперфективації (Городенська та ін., 2017, сс. 396-397; Соколова, 2003, с. 71; Стрекалова, 1979, с. 29). Щодо особливостей творення дієслів вийти і виходитu, wzejść і wschodzić і под., то підтримуємо думку російського мовознавця М. Кронгауза, згідно з якою в дієслівній парі зайти (док.) / заходити (недок.) імперфективна форма заходити (недок.) утворена достатньо рідкісним суплетивним способом від дієслова доконаного виду зайти (Кронгауз, 1998, с. 104). Це дозволяє розглядати такі дієслова не як дві самостійні СП від дієслів йтu / iść і ходитu / chodzić, а в межах однієї і вважати, що вони перебувають між собою у формозмінних, а не словотвірних відношеннях.

Як відомо, лексичні, семантико-граматичні особливості вершинного слова, його структура, валентність, активність та сфера функціонування детермінують кількісний та якісний параметри конкретних СП 
(Berend, 2003 та ін.). Тому важливо окреслити ці параметри твірних у зіставлюваних мовах. В утворенні аналізованих дієслів беруть участь 10 префіксів в українській мові і 12 в польській. 3-поміж цих афіксів $\epsilon$ ті, які виражають значення «переміщення вгору» в обох мовах (в- / w-, ви- / wy-, до- / do-, за- / za-, 3-(c-) / z-(s-), під- / pod, y- / u-), так і ті, що виявлено в одній із мов (при-, na-, po-, wz-). Найбільш продуктивними $\epsilon$ префікси ви- / wy-, під- / pod-, 3-(c-), w-. Напр.: Не хочу злетіти над ліжком, як птаха, не маю бажання зафільмувати зверху (М. Матіос). Niepokój szumi $w$ warszawskim wietrze, Stada jaskółek $w$ górę wzleciały To tylko z chwastów, $z$ ścierni sczerniałych Wilgoć trująca sączy się w przestrzeń (J. Liebert).

Мотиваторами префіксальних дієслів зі значенням «переміщення вгору» виступають дієслова на позначення руху (укр. вибігти / вибігати $3^{2}$, вилізти / вилізати, вилазити 2, злетіти / злітати 1, підскочити / підскакувати 1, а та ін.; пол. podciagnąć / podciagać 1, wyskoczyć / wyskakiwać 2, wzlecieć / wzlatać, wzlatywać 1 та ін.), лексеми інших семантичних груп (укр. вибратися / вибиратися 4, підбитися / підбиватися 1 та ін.; пол. wzbić / wzbijać, wydobyć / wydobywać 1), прикметники (укр. підвищити / підвищувати 1 та ін.; пол. podwyższyć / podwyższać 1 та ін.), що певною мірою визначає їхню активність у продукуванні ними похідних, впливає на склад СП, на чому неодноразово наголошують дослідники (Грещук та ін., 2007; Земская та ін., 1993; Кушлик, 2015; Nagórko, 2007 та ін.). Пор.:

підкинути / підкидати, підкидувати $1 \rightarrow$ підкидання, підкинення, підкидач, підкиданий, підкидниц̆, підкинений, підкинутий, підкинутися / підкидатися, підкидуватися, попідкидати;

вибратися / вибиратися $4 \rightarrow$ повибиратися;

підвищити / підвищувати $1 \rightarrow$ підвищення, підвищування, підвищувач 'той, хто підвищує що-небудь', підвищуваниц, підвищувальний (спец.) 'призначений для підвищування чого-небудь', підвищений, підвищитися / підвищуватися;

${ }^{2}$ Рубрикацію (індексацію) значень префіксальних дієслів та їхніх похідних здійснено за тлумачними словниками української і польської мови з фіксуванням стилістичних і функціональних маркувань, а відтінки позначено літерами відповідного алфавіту, напр.: wylecieć / wylatywać 2 'wzbijać się, być wyrzucanym w górę’ («Wylatywać», 6.p.), вилізти / вилазити, вилізати 2 'підніматися нагору, лізучи, чіпляючись за що-небудь' («Вилазити», б.р. та ін.). 
wzejść / wschodzić $1 \rightarrow$ wschodzenie, wzejście, wschodek (daw.) 'schodek, stopień', wschód 1 'ukazanie się Słońca nad linią horyzontu', wschód 2 'miejsce, gdzie ukazuje się wschodzące słońce', wschód 6 (daw.) 'schody', powschodzić;

wzbić / wzbijać $\rightarrow$ wzbicie, wzbijanie, wzbity, wzbijajacy, wzbijany, wzbić się / wzbijać się;

wywyższyć / wywyższać 2 (daw.) $\rightarrow$ wywyższenie, wywyższanie, wywyższany, wywyższony, nawywyższać, powywyższać.

Як бачимо, віддієслівні префіксальні дієслова зі значенням «переміщення вгору», мотиваторами яких є дієслова на позначення руху, у зіставлюваних мовах мають значно більші за компонентним складом конкретні СП.

Структура та семантика СП префіксальних дієслів зі значенням «переміщення вгору» зумовлена валентнісними особливостями твірних дієслів. На думку І. Р. Вихованця, творення іменників спирається на семантико-синтаксичну структуру речення, а отже, деривація таких утворень регулюється відповідними іменниковими синтаксемами. Відповідно до заміщуваних синтаксичних конструкцій синтаксемних позицій речення можна виділити ряд словотвірних категорій іменника, якими є суб’єкт дії, стану, знаряддя дії, місце [...] (Вихованець, 1988, c. 134). Названі значення на рівні словотвору можуть бути виражені похідними іменниками. Твірні дієслова означають процеси переміщення і передбачають валентні позиції суб’єкта, об’єкта, інструмента, місця. Ці семантичні гнізда в мові представлені відповідними субстантивами, напр., суб'єкт (виконавець) - укр. підвищувач, пол. wspinacz, об’єкт - podrzut 3 (daw., rzad.), інструмент (знаряддя) - укр. підйом 6, пол.podciag 2 (żegl.), місце - укр. вивіз 3 (діал.), пол. wschód 2 тощо.

О. А. Земська пропонує розрізняти два види парадигм - конкретну СП і типову СП. Досліджуваний матеріал проаналізуємо на рівні СП з погляду структури і семантики. Конкретна СП - це сукупність слів, що мотивуються тим самим твірним і перебувають на одному ступені творення (Земская та ін., 1993, с. 250). Типова СП складається із С3 (= семантичних місць), які реалізують твірні слова певної частини мови, що входять до однієї лексико-семантичної групи (Земская та ін., 1993, c. 250; Манучарян, 1983, с. 9), це абстрактна матриця, яку можна заповнювати конкретним лексичним матеріалом (Земская та ін., 1993, с. 250; 
Nagórko, 2007, с. 231), тобто це штучно створена мова-еталон (конструкт), яку ми отримуємо на основі аналізу конкретних СП. Тому проаналізуємо конкретні СП префіксальних дієслів зі значенням «переміщення вгору», щоб на цій основі побудувати типову СП.

Приклади засвідчують, що конкретні СП префіксальних дієслів зі значенням «переміщення вгору» в межах окремо української і польської мов не завжди є однорідними за якісним і кількісним складом. Словотвірна парадигматика досліджуваних дієслів охоплює різні за лексико-семантичним наповненням конкретні СП, серед яких виокремлюємо:

1) СП, у яких не засвідчено похідних: укр. вибуксирувати, викарабкатися / викарабкуватися (розм.), витеребитися² (фам.), вишкрябатися / вишкрябуватися (розм.), з’іхати / з'їджати (розм.), з’іздити 8 (заст.), угнати (вгнати) / уганяти² (вганяти) 3 (розм.) та ін.; пол. wygramolić się (pot.), wynurkować (rzad.), zagramolić się (rzad.). Немає ніяких перешкод для утворення таких дериватів, тому можна прогнозувати і подальшу появу подібних девербативів. Це підтверджують іменники зі значенн ям «опредметнена дія», які не фіксують тлумачні словники: підкинення, підскакування (ВЗОССУЛ, 2003).

2) словотвірні парадигми, які складаються з одного частиномовного блоку:

- субстантивного: укр. збігти / збігати $6 \rightarrow$ збігання, сплигнути / сплигувати $2 \rightarrow$ сплигування та ін.; пол. wydrapać się / wydrapywać się 1 (pot.) $\rightarrow$ wydrapanie się, wydrapywanie się, uciągnąć 2 (daw.) a $\rightarrow$ uciagnięcie, uciagnienie, wgramolić się (pot.) $\rightarrow$ wgramolenie się та ін.;

- ад'єктивного: укр. підпливти, підплисти / підпливати $3 \rightarrow$ підплилий;

- вербального: укр. вибратися / вибиратися $4 \rightarrow$ повибиратися, вибігти / вибігати $3 \rightarrow$ повибігати, вийти / виходити $4 \rightarrow$ повиходити, залізти / залізати, залазити1 $1 \rightarrow$ позалазити та ін.; пол.родfrunąć / podfruwać $\rightarrow$ popodfruwać;

- адвербіального: укр. пристрибнути / пристрибувати ${ }^{2} \rightarrow$ пристрибом;

3) словотвірні парадигми, які складаються з двох частиномовних блоків:

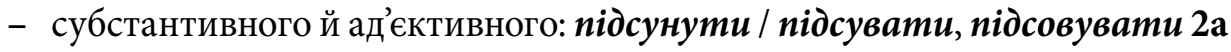
$\rightarrow$ підсування, підсунений, підсунутий; пол. wspiąć się / wspinać się 1 $\rightarrow$ wspięcie się, wspinanie się, wspinalnia 'drabinki służące dzieciom do wspinania', wspinacz 'osoba, która uprawia wspinaczkę', wspinaczka 
'wchodzenie na szczyty stromych skał lub gór', wspinający się, wwieźć / wwozić $2 \rightarrow$ wwiezienie, wwożenie, wwieziony, wwożacy, wwożony та ін.;

- субстантивного й вербального: вивищити / вивищувати 1 $\rightarrow$ вивищення, вивищитися / вивищуватися, виїхати / виїздти, виїжджати $3 \rightarrow$ виїзд 3 'коні з екіпажем', повиїздити, повиїжджати, вилетіти / вилітати 1а, $2 \rightarrow$ виліт 1, 2, повилітати, злетіти / злітати $1 \rightarrow$ зліт 1, злітання, позлітати та ін.; пол. podlecieć / podlatać (daw.), podlatywać $1 \rightarrow$ podlecenie, podlot 1 'wzlot do góry', podlatanie, podlatywanie, popodlatać (daw.), popodlatywać; podjać / podejmować $\rightarrow$ podjęcie, podejmowanie, podją́ się / podejmować się та ін.;

- субстантивного й адвербіального: підлетітu / niдлітати $3 \rightarrow$ niдлim, підлітання, підлетом;

4) словотвірні парадигми, які об'єднують три частиномовні блоки похідних одиниць, наприклад:

- субстантивний, адєктивний і вербальний: укр. вивезти / вивозити 3а $\rightarrow$ вивіз 1, 3 (діал.), вивозка, вивезення, вивезений, повивозити, підняти, підійняти / піднімати, підіймати $1 \rightarrow$ піднімання, підіймання, підняття 1 , підйом 1, піднімальний, підіймальний, підйомний 1а, піднятий, підійнятий, піднімаючий, попіднімати, попідіймати, піднятися, підійнятися / nідніматися, підійматися та ін.; пол. wynieść / wynosić $\mathbf{2} \rightarrow$ wyniesienie, wynoszenie, wyniesiony, wynoszony, wyniosty 4 (daw.) 'wzniesiony do góry', wynieść się / wynosić się 3, powynosić, nawynosić; doskoczyć / doskakiwać 2 $\rightarrow$ doskoczenie, doskakiwanie, doskakujący, podoskakiwać та ін.;

- субстантивний, вербальний та адвербіальний: укр. вискочити / вискакувати $2 \rightarrow$ вискакування, вискік 1, вискокнути, повискакувати, вискоком, вистрибнути / вистрибувати $2 \rightarrow$ вистрибування, повистрибувати, вистриби (рідко), вистрибом, вистрибием, підскочити / підскакувати'1 1 $\rightarrow$ підскік, підскок, підскакування, підскоком (розм.), попідскакувати.

Як бачимо, у префіксальних дієслів зі значенням «переміщення вгору» в українській і польській мовах виявлено 10 структурних типів конкретних СП, з яких 6 є спільними для обох мов, а 4 типи реалізують лише українські префіксальні дієслова.

3 аналізу структури конкретних СП бачимо, що від префіксальних дієслів в українській і польській мові утворюються іменники, прикметники, дієслова та прислівники. Найбільш репрезентативним у зіставлюваних мовах є субстантивний блок, який відзначається найбільшою різнома- 
нітністю СЗ. Кількісно найбільше представлено С3 «опредметнена дія». Деривати із цим СЗ утворюються переважно за допомогою суфіксів. У творенні цих іменників найактивнішими є суфікси -нн- (-енн-) / -n(укр. вивезення, вивищення, вилізання, витягання, витягнення, витягування, винесення, виплигування, закидання, злітання, підвищення, підвищування, підкидання, піднімання, підстрибування та ін.; пол. podciagnienie, podciaganie, podlezienie, podłażenie, podniesienie, podskoczenie, podskakiwanie, wzlatanie, wzlatywanie, schodzenie, wydrapywanie sie, zarzucenie, zarzucanie та ін.), Ø (укр. вивіз 1, виїз 1, винос, вискік, зліт, знос 1 , підйом 1, підліт, підскок, підскік та ін.; пол. podjazd 4, podlot 1, podrzut 1, podskok 1, 2, wzlot 1, wschód 1, wyłaz та ін.), -тт- / -c'- (укр. підняття 1; пол.podjęcie, wzejście, wspięcie się, wciagnięcie, wbiegnięcie, zejście та ін.), у словниках виявлено поодинокі приклади із суфіксом -к- (вивозка, підтяжка 1), які не відповідають нормам літературної мови, -ин- (сходини 3 (рідко)). Назване С3 реалізують і складні деривати (суднопідіймання, суднопіднімання).

Досліджувані префіксальні дієслова часто утворюють похідні зі значенням «знаряддя дії», виразниками якого виступають форманти -ач (піднімач (мед.) 'хірургічний інструмент', підтягач), Ø (укр. підйом 6 'пристрій, пристосований для піднімання чого-небудь', сходи' 'горизонтальні виступи, перекладини, на які ступають, піднімаючись куди-небудь' та ін.; пол. podciąg 2 (żegl.) 'lina umożliwiająca podciągnięcie żagla', wciag (techn.) 'urządzenie do podnoszenia lub przesuwania ciężarów', wschód 6 (daw.) b 'schody'), -к- (сходки (діал.) 'східці', підтяжка 2), -ник / -nik (-nic-) (укр. підйомник 'ліфт’; пол. podnośnik (techn.) 'urządzenie mechaniczne do podnoszenia przedmiotów na określoną wysokość, podciagnik (górn.) 'przyrząd do podciągania', wciągnik (techn.) 'uproszczony typ wciągarki’, podnośnica (mors.) 'lina, za pomocą której podciąga się w górę żagiel', wyciagnik 'urządzenie zaopatrzone w linę lub łańcuch, służące do wydobywania i podnoszenia'), -ц- (східиі 'горизонтальні виступи, перекладини, на які ступають, піднімаючись куди-небудь'), -ин- (сходина), -н- (сходні 'трап'), -ln- (wspinalnia 'drabinki służące dzieciom do wspinania'), -ark- (wciagarka (techn.) 'urządzenie do podnoszenia lub przesuwania ciężarów’, wyciagarka). У конкретній СП дієслова підняти, підійняти / піднімати, підіймати фіксуємо і складні деривати (стеблепіднімач, суднопідіймач, суднопідйомник, сінопідіймач, сінопіднімач).

У низці конкретних СП виявлено іменники із С3 «місце дії», утворені за допомогою суфіксів Ø (укр. вивіз 3 (діал.) 'ділянка дороги, що 
має схил; узвіз', виїзд 2 'місце, яким виїжджають звідки-небудь', підйом 2 'ділянка дороги, що веде вгору', схід1 2 'частина обрію, де сходить сонце', cxid2 2 'дорога, по якій піднімаються вгору'; пол. wschód 2 'miejsce, gdzie ukazuje się wschodzące słońce', podjazd 6 (sport.) 'część trasy wiodąca pod górę', wyłaz 'otwór służący do wychodzenia na dach', wbieg (indyw.) 'miejsce, droga wbiegnięcia'), -ówk- podjazdówka 3 'odcinek drogi, na którym wznosi się ona do góry'), «виконавець дії» - суфіксів -ач (укр. підвищувач 'той, хто підвищує що-небудь' та ін.; пол. wspinacz 'osoba, która uprawia wspinaczkę') та «об'єкт дії» (wyrzut 1b 'to, co zostało wyrzucone', podrzut 3 (daw., rzad.) 'obiekt, przedmiot').

У семантичній структурі деяких похідних субстантивів, крім транспозиційного значення «опредметнена дія» розвивається мутаційне значення «місце дії» (укр. підйом 2, вивіз 3 (діал.), виїзд 2, схід 2 2, схід 1 2; пол. wschód 2, podjazd 6 (sport.)), «знаряддя дії» (nідйом 6), «об’єкт дії» (podrzut 3 (daw., rzad.)). Напр.: Жінка у візку, що спитала когось із персоналу, де тут підйомник для інвалідів (Ю. Андрухович). Він на одному диханні підтягнувся 25 разів, потім якимось невловимим рухом зробив ще одне підтягання $і$ несподівано виконав стійку на руках, а тоді поплескав y nовітрі ногами (С. Гридін). Otóż dużo wcześniej, jeszcze przed wschodem słońca, w łudzacej wzrok szarówce, wydawało mi się, że jeden $z$ kogutów jest odpowiednio blisko (A. Otrębski). Pod koniec lipca tego roku w rejonie Wierchu pod Fajki odpadł z ruchomym blokiem młody wspinacz (M. Jagiełło).

I в українській, і в польській мові в структурах конкретних СП префіксальних дієслів зі значенням «переміщення вгору» засвідчено прикметники. Ад'єктивний блок сформований девербативами із С3 «ознака суб'єкта за дією», засобами реалізації якого є суфікси -юч-, -яч- / -а̨с- (піднімаючий, спливаючий, сходячий (рідко), які не відповідають словотвірним нормам української мови і $є$ свідченням впливу російської мови; пол. doskakujący, podchodzacy, podjeżdzajacy, podskakujący, wyjeżdzajacy, wylatujący, wschodzacy, wzlatający, wznoszący та ін.), «ознака об’єкта за дією», виразниками якого виступають форманти -ен- / -on-, -т- / -t-, -ан- / -an- (укр. винесений, витягнений, закинений, підвищениц, підтягнений, витягнутици, підкинутий, підтягнутий, піднятий, підтягуваний; пол. podciągany, podciagnięty, uniesiony, unoszony, wciagany, wciagnięty, wzniesiony, wznoszony, podniesiony, podnoszony та ін.) та «призначений для того, на що вказує твірна основа» - -льн- (витягувальний (техн.), витягальний (спец.), підвищувальний (спец.), піднімальний, підіймаль- 
ний, суднопідіймальний, суднопіднімальний), -н- / -n- (укр. підйомний 1а 'признач. для піднімання', підкидний); пол. podnośny (techn.) 'służący do podnoszenia na małą wysokość). Напр.: Знизу вона нагадувала прапор, піднятий із нагоди державного свята (С. Жадан). Каt miecz wzniesiony opuścit, skazaniec zadygotał całym ciałem, a pan pisarz miejski, zdjęte dopiero co okulary z powrotem na nos sążnisty założywszy, niechętnie spojrzał na rajce oczekując wyjaśnienia sprawy (A. Oppman).

У межах вербального блоку виділяємо префіксальні, суфіксальні і постфіксальні (у польській мові за допомогою зворотного займенника) девербативи з такими С3: «дистрибутивність дії» (укр. повискакувати, повистрибувати, повибиратися, повиїджати, повилазити, повилізати, повитягувати, повитягати, попіднімати, попідіймати та ін.; пол. popodlatywać, powyłazić 2 (pot.), powylatać, powylatywać 2, powyskakiwać, popodrzucać, popodciagać, powznosić та ін.), «виконуючи дію, переводити щось зі стану об'єкта в стан суб'єкта» (укр. вивищитися / вивищуватися, здійнятися / здійматися, піднятися / підніматися, підійматися та ін.; пол. podciagnąć się / podciagać się, unieść się / unosić się, wynieść się / wynosić się 3, wznieść się / wznosić się, podjąć się / podejmować się, podnieść się / podnosić się 2 та ін.), «кумулятивність дії» (укр. навикидати, навитягати (розм), назво́дити; пол. napodciągać, napodwyższać, nawznosić, naunosić, napodrzucać, napodnosić, nawywyższać та ін.) та «однократність діiі» (nidстрибнути, вискокнути (рідко)). Напр.: Якби ж знав, то, може, спробував собі здійнятися у небо і хтозна, чи не перетворилися б з великої любові Іванові руки на крила (В. Лис). Łatwiej jednak spadać, niż wznieść się w górę (J. Dzik).

Зрідка досліджувані префіксальні дієслова породжують прислівники із СЗ «адвербіалізація дії» (виплигом (діал.), вискоком, вистриби (рідко), вистрибом, вистрибием, підскоком (розм.), підстрибом (розм.), nідстрибием (розм.)), яке формує адвербіальний блок. Напр.: 3 ними юрбою, з вискоком, трохи не з вибриком, пішли молоді гості на парадовий прихід з улиці (І. Нечуй-Левицький).

Отже, типова СП префіксальних дієслів зі значенням «переміщення вгору» в зіставлюваних мовах має чотириблочну структуру з такими семантичними позиціями в кожному із блоків: субстантивний - «опредметнена дія», «виконавець дії», «знаряддя дії», «місце дії», «об’єкт дії»; ад’єктивний «ознака суб’єкта за дією», «ознака об’єкта за дією», «призначений для того, на що вказує твірна основа»; вербальний - «дистрибутивність дії», «куму- 
лятивність дії», «виконуючи дію, переводити щось зі стану об’єкта в стан суб’єкта», «однократність дії»; адвербіальний - «адвербіалізація дії».

Таблиця 1. Типова словотвірна парадигма префіксальних дієслів зі значенням «переміщення вгору» та тї̈ наповнення в українській і польській мовах

\begin{tabular}{|c|c|c|c|}
\hline Блоки & $\begin{array}{c}\text { Типова словотвірна } \\
\text { парадигма }\end{array}$ & Українська мова & Польська мова \\
\hline \multirow{5}{*}{ 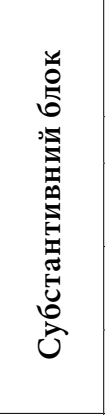 } & Опредметнена дія & $\begin{array}{l}\text { вилізання, виїз 1, витяг- } \\
\text { нення, зліт, підкидання, } \\
\text { підйом } 1\end{array}$ & $\begin{array}{l}\text { podciagnięcie, podlecenie, } \\
\text { podskok, wydrapywanie się }\end{array}$ \\
\hline & Виконавець дії & підкидач & wspinacz \\
\hline & Знаряддя дії & підйомник, підтягач & $\begin{array}{l}\text { podnośnik (techn.), wspi- } \\
\text { nalnia }\end{array}$ \\
\hline & Місце дії & виїзд 2, підйом 2 & $\begin{array}{l}\text { wschód 2, podjazd } 6 \\
\text { (sport.) }\end{array}$ \\
\hline & Об’єкт дії & - & $\begin{array}{l}\text { wyrzut } 1 \mathrm{~b}, \text { podrzut } 3 \text { (daw., } \\
\text { rzad.) }\end{array}$ \\
\hline \multirow{3}{*}{ 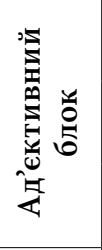 } & $\begin{array}{l}\text { Ознака суб’єкта за } \\
\text { дією }\end{array}$ & $\begin{array}{l}\text { піднімаючиц̆, спливаю- } \\
\text { чий }\end{array}$ & wyjeżdżajacy, wzlatajacy \\
\hline & Ознака об’єкта за дією & $\begin{array}{l}\text { витягнениц̆, підкину- } \\
\text { тий, піднятий }\end{array}$ & $\begin{array}{l}\text { podciagany, podciagnięty, } \\
\text { uniesiony }\end{array}$ \\
\hline & Призначений для... & $\begin{array}{l}\text { витягальний (спец.), } \\
\text { піднімальний }\end{array}$ & podnośny (techn.) \\
\hline \multirow{5}{*}{ 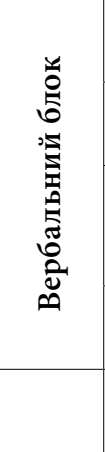 } & Дистрибутивність дії & $\begin{array}{l}\text { повискакувати, попідні- } \\
\text { мати }\end{array}$ & $\begin{array}{l}\text { popodlatywać, powyłazić } 2 \\
\text { (pot.) }\end{array}$ \\
\hline & Кумулятивність дії & $\begin{array}{l}\text { навикидати, навитя- } \\
\text { гати (розм.) }\end{array}$ & napodwyższać, nawznosić \\
\hline & $\begin{array}{l}\text { Виконуючи дію, пере- } \\
\text { водити щось зі стану } \\
\text { об'єкта в стан суб’єкта } \\
\end{array}$ & піднятися / підніматися & podnieść się / podnosić się 2 \\
\hline & Однократність дії & $\begin{array}{l}\text { підстрибнути, вискок- } \\
\text { нути (рідко) }\end{array}$ & - \\
\hline & Адвербіалізація дії & $\begin{array}{l}\text { вискоком, підскоком } \\
\text { (розм.) }\end{array}$ & - \\
\hline
\end{tabular}

На основі аналізу СП прослідкуємо, як реалізують словотвірний потенціал префіксальні дієслова зі значенням «переміщення вгору» в українській і польській мовах за такими параметрами: 1) за структурою СП, тобто здатність твірних однієї ЛСГ породжувати похідні різних блоків; 2) СЗ типової СП, реалізовані похідними в кожній із зіставлюваних мов; 3) статистична формула СП (див. таблицю 2); 4) міра відповідності дери- 
ваційної спроможності еквівалентних твірних слів досліджуваної групи; 5) співвідносні корпуси словотворчих формантів, задіяні в реалізації С3 типової СП; 6) способи творення девербативів у кожній із мов.

1. В українській мові префіксальні дієслова зі значенням «переміщення вгору» породжують деривати всіх чотирьох блоків, натомість у польській мові не виявлено девербативів адвербіального блоку, тобто частиномовних блоків лише три, тому відмінності спостерігаємо в структурній організації СП зіставлюваних мов (див. таблицю 1).

2. Повний набір СЗ типової СП не реалізує жодна конкретна СП зіставлюваних мов. У результаті аналізу реалізації словотвірного потенціалу досліджуваних префіксальних дієслів виявлено як подібності, так і відмінності. 313 С3 типової СП обидві мови заповнюють 10 семантичних позицій, водночас в українській мові лакунарною $є$ позиція «об'єкт дії», а в польській не реалізованими виявилися семантичні місця «однократність дії» та «адвербіалізація дії» (див. таблицю 1). У субстантивному блоці в зіставлюваних мовах найбільш кількісно представлено С3 «опредметнена дія», яке більш послідовно реалізується в польській мові. Девербативи із С3 «опредметнена дія» відзначені в СП 48,6\% префіксальних дієслів української мови та 81,1\% твірних польської мови. У цьому плані польські префіксальні дієслова $є$ більш регулярними, в окремих випадках в українській мові спрацьовують формальні обмеження (укр. вийти 4, зійти 1 - відсутні іменники nomina actionis; пол. wejść $\rightarrow$ wejście, zejść $\rightarrow$ zejście). Проте розбіжності в наборі дериватів конкретної СП і заповненні семантичних місць не завжди зумовлені обмеженнями. Іноді їхня відсутність зумовлена позамовними чинниками - відсутністю потреби в дериваті (пор.: укр. вилізти 2, підлетіти 3, підскочити 1 та ін., від яких не зафіксовано у словниках таких іменників; пол. wyleźć 2 (pot.) $\rightarrow$ wylezienie, podlecieć $1 \rightarrow$ podlecenie, podskoczyć $1 \rightarrow$ podskoczenie, podejść $\rightarrow$ podejście 2 та ін.). Як слушно зауважує А. Нагурко, це носії мови визначають, які можливості мовної системи будуть ними використані (Nagórko, 2007, с. 235).

Однією з важливих ознак СП є їі глибина. Розгортання СП у глибину передбачає заповнення однієї семантичної позиції дериватами з різнозвучними формантами. Розглянемо цю особливість СП на прикладі С3 «опредметнена дія». За нашими спостереженнями глибина СП сягає від 2 до 4 дериватів. У зіставлюваних мовах переважно це двочленні СП 
(укр.злітання, зліт; піднос, піднесення; пол. podciaganie, podciagnięcie; podjęcie, podejmowanie; podlecenie, podlot 1 та ін.), рідше тричленні (укр. сходження, схід2 1, сходини 3 (рідко) та ін.; пол. wchodzenie, wchód (daw.) b, wejście та ін.), в окремих випадках чотиричленні, які виявлено в СП української мови (піднімання / підіймання, підйом 1, підняття 1, суднопідіймання / суднопіднімання).

3. Результатом унаочнення аналізу структурного аспекту СП $є$ поняття статистичної формули, якою послуговується ціла низка мовознавців щодо словотвірного гнізда (С. П. Гірняк, Т. Є. Санаєва, О. М. Тихонов; Ярошенко, 2007 та ін.) і яку видозмінюємо під параметри СП. Запропонований варіант параметрів статистичної формули СП не є остаточним, його можна змінювати, доповнювати іншими ознаками цієї комплексної одиниці. На думку Н. О. Ярошенко, статистична формула є зручним інструментом для зіставно-типологічного дослідження, оскільки являє собою один зі шляхів виявлення й узагальнення спільного й відмінного у структурі зіставлюваних гнізд (Ярошенко, 2007, с. 426).

Свій словотвірний потенціал префіксальні дієслова зі значенням «переміщення вгору» в обох мовах реалізують переважно на рівні субстантивного словотворення, менш регулярними є утворення ад'єктивних і дієслівних лексем і зовсім нерегулярним - утворення адвербіальних похідних. Спостерігаємо розбіжності в кількісному співвідношенні похідних у зіставлюваних мовах як в окремих семантичних позиціях, так і структурних блоках, зокрема польські іменники і прикметники кількісно вдвічі перевищують аналогічні утворення в українській мові, тоді як вербальні блоки майже однакові (таблиця 2). Впадає в око значна розбіжність у зіставлюваних мовах (укр. - 23,9\%, пол. $-4,3 \%$ ) у кількості твірних, щодо яких спрацьовують різні мовні і позамовні обмеження на породження похідних, тобто мають нульові СП, що зумовлено переважно стилістичним маркуванням українських лексем (пор.: викарабкатися / викарабкуватися (розм.), викараскатися (розм.), викотитися / викочуватися (розм.), витеребитися² (фам.), вишкрябатися / вишкрябуватися (розм.), угнати (вгнати) / уганяти (вганяти) 3 (розм.) та ін.).

Навіть побіжний аналіз СП дозволяє констатувати, що префіксальні дієслова зі значенням «переміщення вгору» продуктивні в утворенні девербативів. Так, в українській мові від 71 лексико-семантичного варіанта префіксальних дієслів утворено 180 девербативів різних лексико-граматич- 
них класів, а в польській мові на долю 68 твірних припадає 311 дериватів. 3 цього випливає, що в кожній мові можна обрахувати середню кількість дериватів однієї СП як співвідношення загальної кількості девербативів до кількісного набору твірних. Наприклад, в українській мові середня кількість однієї СП українських префіксальних дієслів зі значенням «переміщення вгору» складає $180: 71=2,5$, а в польській - $311: 68=4,5$. На основі цього можна зробити висновок, що середня кількість дериватів в одній СП польської мови майже вдвічі вища від української $(4,5: 2,5)$.

4. Через те, що кількість дієслів-еквівалентів у зіставлюваних мовах досліджуваної групи становить приблизно лише третину від загальної кількості твірних, залишимо вивчення цієї проблеми на матеріалі інших семантичних груп у наступних публікаціях.

5. Зіставлення засобів вираження СЗ типової СП, за словами дослідників, дасть змогу побачити активність словотворчих засобів, їхню продуктивність в утворенні дериватів певних значень, а також виявити ті, які характерні тільки для однієї з мов. На основі зіставлення СП префіксальних дієслів зі значенням «переміщення вгору» можна стверджувати, що одні засоби беруть участь у реалізації С3 в обох мовах (C3 «опредметнена дія» - -нн- (-енн) / -n-, Ø; С3 «ознака об’єкта за дією» - -т- / -t-; C3 «місце діï» - Ø та ін.), при цьому такі засоби відрізняються продуктивністю, тобто за допомогою цих формантів в одній мові утворюється чимало похідних, в іншій - поодинокі деривати (С3 «опредметнена дія» - -тт- / -c'-; C3 «знаряддя дії» - -ник / -nik (-nic-); С3 «ознака суб’єкта за дією» - -юч-, -яч- / -а̨с- та ін.), а також виявити ті, які характерні лише для однієї з мов (укр. С3 «знаряддя дії» - -ач; пол. С3 «знаряддя дії» - -ark- тощо).

6. Основними способами творення девербативів у межах СП в українській і польській мовах є суфіксація і префіксація. Водночас в українській мові на базі префіксальних дієслів зі значенням «переміщення вгору» утворюються і композити (суднопідіймач, сінопіднімач, сінопідіймач, стеблепіднімач, суднопіднімання), що може бути зумовлено тенденцією до аналітизму польської мови в порівнянні з українською (пор.: укр. атомохід - пол. statek atomowy).

Отже, зіставний аналіз СП префіксальних дієслів зі значенням «переміщення вгору» в українській і польській мові засвідчив значний словотвірний потенціал цих дериватів в обох мовах і виявив як спільності, так і відмінності. 
Таблиця 2. Статистична формула СП префіксальних дієслів зі значенням «переміщення вгору» в українській і польській мовах

\begin{tabular}{|c|c|c|c|c|c|c|c|c|c|c|c|c|c|}
\hline \multirow[b]{2}{*}{ 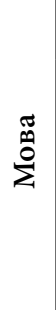 } & \multirow{2}{*}{ 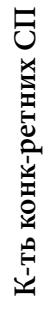 } & \multirow[b]{2}{*}{ 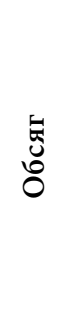 } & \multirow{2}{*}{ 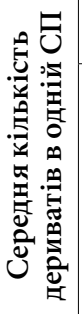 } & \multicolumn{4}{|c|}{ Протяжність } & \multirow{2}{*}{ 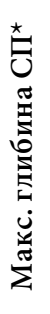 } & \multirow{2}{*}{ 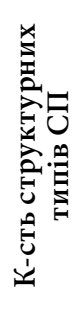 } & \multirow{2}{*}{ 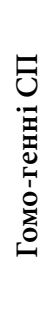 } & \multirow{2}{*}{ 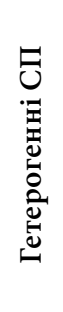 } & \multirow{2}{*}{ 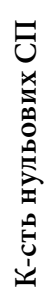 } & \multirow{2}{*}{ 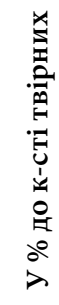 } \\
\hline & & & & 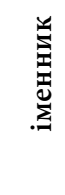 & 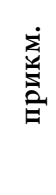 & 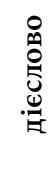 & 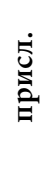 & & & & & & \\
\hline 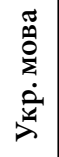 & 71 & 180 & 2,5 & 85 & 34 & 53 & 8 & 4 & 10 & 9 & 45 & 17 & 23,9 \\
\hline 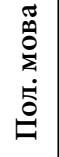 & 68 & 311 & 4,5 & 156 & 81 & 69 & - & 3 & 6 & 11 & 54 & 3 & 4,3 \\
\hline
\end{tabular}

* глибину словотвірної парадигми визначено на базі словотвірного значення «опредметнена дія», у межах якого спостерігається найбільша кількість різноформантних дериватів.

\section{Скорочення}

ВЗОССУЛ - Великий зведений орфографічний словник сучасної української лексики, 2003

ВТССУМ - Великий тлумачний словник сучасної української мови, 2001

ЛСГ - лексико-семантична група

С3 - словотвірне значення

СП - словотвірна парадигма

СУМ - Словник української мови, 1970-1980

СУМГ - Словарь української мови (Грінченко, 1996)

SGSWJO - Słownik gniazd słowotwórczych współczesnego języka ogólnopolskiego. T. 3. Gniazda odczasownikowe (Skarżyński, Berend [et al.]), 2004

SJPD －Słownik języka polskiego, 1958-1969

WSJP - Wielki słownik języka polskiego 


\section{Бібліорафія}

Бразаускене, Е. М. (1991). Словообразовательный потенциал пребиксальных глаголов современного русского языка [Summary of doctoral dissertation]. Академия наук СССР, Институт русского языка.

Бузашшиова, К. (1987). Возможности и границы моделирования на уровне словообразовательных парадигм. In Сопоставительное изучение словообразования славянских языков (рр. 14-19). Наука.

Валюх, 3. О. (2013). Словотвірна парадигма як об'єкт зіставної типології. Науковий вісник кафедри ЮНЕСКО Київського національного лінгвістичного університету: Філологія, педагогіка, психологія, 27, 6-10. http://nbuv.gov.ua/UJRN/Nvkyu_2013_27_3

Великий зведений орфографічний словник сучасної украйнської лексики [ВЗОССУЛ]. (2003). ВТФ «Перун».

Великий тлумачний словник сучасної украӥнської мови [ВТССУМ]. (2001). ВТГ «Перун».

Вилазити. (n.d.). In Академічний тлумачний словник української мови. Retrieved September 13, 2021, from http://sum.in.ua/s/vylazyty

Вихованець, І. Р. (1988). Частини мови в семантико-граматичному аспекті. Наукова думка.

Городенська, К. Г. (Еd.), Вихованець, І. Р., Загнітко, А. П., \& Соколова, С. О. (2017). Граматика сучасної української літературної мови: Морфологія. Видавничий дім Дмитра Бураго.

Грінченко, Б. Д. (1996). Словарв української мови [СУМГ] (Vols. 1-4). Наукова думка.

Грещук, В. В., Бачкур, Р. О., Джочка, І. Ф., \& Пославська, Н. М. (2007). Нариси з основоцентричної дериватологї. Місто НВ.

Земская, Е. А., Ермакова, О. П., \& Рудник-Карват, 3. (1993). Теоретические проблемы сопоставительного изучения словообразования славянских языков (семантико-функциональный аспект). In Славянское языкознание: ХІ Международный съезд славистов: Доклады российской делегации: Сб. докладов (рр. 248-263). Наука.

Клименко, Н. Ф. (1991). Словообразовательные гнезда слов как объект типологического изучения. In Актуальные проблемы русского словообразования: Материаль VI респ. научн.-практ. конф. Самарканд (рp. 81-83). [n.p.].

Клименко, Н. Ф., Пещак, М. М., \& Савченко, І. С. (1982). Формалізовані основи семантичної класифікації лексики. Наукова думка.

Ковалик, I. I. (1969). Порівняльно-типологічне вивчення словотвірних структур споріднених мов. In Питання словотвору східнослов'янських мов: Матеріали міжвуз. республ. наук. конф. (рр. 4-7). Наукова думка.

Кронгауз, М. А. (1998). Приставки и глаголь в русском языке: Семантическая грамматика. Школа «Языки русской культуры».

Кушлик, О. П. (2015). Словотвірна парадигматика похідних дієслів в украӥнській мові. Коло. 
Манучарян, Р. С. (1983). Словообразовательная парадигма и сопоставительно-типологический аспект словообразования. In Русский язык: Вопросы теории и методики: Cб. статей (Vol. 2, pp. 5-15). Издательство Ереванского университета.

Нещименко, Г. П. (1983). О некоторых аспектах сопоставительного изучения славянского словообразования. In Сопоставительное изучение грамматики и лексики русского языка с чешским и другими славянскими языками (рр. 30-51). Издательство Московского университета.

Рахилина, Е. В., \& Прокофьева, И. А. (2004). Родственные языки как объект лексической типологии: Русские и польские глаголы вращения. Вопросы языкознания, 2004(1), 60-78.

Сегін, Л. В. (2019). Префіксальні дієслова зі значенням «переміщення вгору» в структурі словотвірної парадигми дієслова в українській мові. Studia z Filologii Polskiej i Słowiańskiej, 54, Article 1735. https://doi.org/10.11649/sfps.1735

Сегін, Л. В. (2020). Типологія словотвірних парадигм префіксальних дієслів зі значенням «переміщення вгору» в польській мові. Studia z Filologii Polskiej i Słowiańskiej, 55, Article 2021. https://doi.org/10.11649/sfps.2021

Словник украӥнської мови [СУМ] (Vols. 1-11). (1970-1980). Наукова думка.

Соколова, С. О. (2003). Префіксальний словотвір дієслів у сучасній украйнській мові. Наукова думка.

Сопоставительное словообразование славянских языков. (1987). Наука.

Стрекалова, 3. Н. (1979). Морфология глагольного вида в современном польском титературном языке. Наука.

Ярошенко, Н. (2007). Статистична формула словотвірного гнізда в зіставному аспекті (на матеріалі російської, української, польської та англійської мов). Лінгвістичні студіi: 36. наук. праць, 15, 425-430.

Berend, M. (2003). Aktywność słowotwórcza czasowników ruchu (opis gniazdowy). In M. Skarżyński (Ed.), Słowotwórstwo gniazdowe: Historia, metoda, zastosowania (pp. 100-106). Księgarnia Akademicka.

Buzássyová, K. (1974). Sémantická štruktúra slovenských deverbatív. Veda.

Doroszewski, W. (Ed.). (1958-1969). Słownik języka polskiego [SJPD] (Vols. 1-11). Wiedza Powszechna.

Jochym-Kuszlikowa, L. (1982). Metoda analizy gniazdowej $w$ konfrontatywnych badaniach słowotwórstwa współczesnego języka polskiego i rosyjskiego (formacje odprzymiotnikowe). Wydawnictwo Naukowe WSP.

Karpiłowska, E. A. (2007). Gniazda słów jako językowy obraz świata: Perspektywy badań porównawczych. LingVaria, 2(2(4)), 27-41.

Koriakowcewa, E. (Ed.). (2010). Aktualne problemy komparatystyki słowiańskiej: Teoria i metodologia badań lingwistycznych. Wydawnictwo Uniwersytetu Przyrodniczo-Humanistycznego. 
Malanowska-Statkiewicz, M. (2017). Potencjał słowotwórczy wybranych czasowników dźwiękonaśladowczych w języku czeskim i polskim. Slavica Wratislavensia, 165, 255-265. https://doi.org/10.19195/0137-1150.165.22

Nagórko, A. (2007). Zarys gramatyki polskiej. Wydawnictwo Naukowe PWN. https://vdocuments.mx /nagorko-alicja-zarys-gramatyki-polskiej.html

Ohnheiser, I. (Ed.). (2003). Komparacja systemów i funkcjonowania współczesnych języków słowiańskich: Vol. 1. Słowotwórstwo/nominacja. Uniwersytet Opolski, Instytut Filologii Polskiej; Opolskie Towarzystwo Przyjaciół Nauk.

Skarżyński, M., Berend, M., Bondkowska, M., Burkacka, I., Jadacka, H., Olejniczak, M., \& Vogelgesang, T. (2004). Słownik gniazd słowotwórczych współczesnego języka ogólnopolskiego: Vol.3. Gniazda odczasownikowe [SGSWJO] (Pt. 1-2). Towarzystwo Wydawnicze «Historia Iagellonica».

Wielki słownik języka polskiego [WSJP]. (n.d.). https://www.wsjp.pl

Wylatywać. (n.d.). In Słownik jezzyka polskiego. Retrieved September 13, 2021, from https://sjp.pwn .pl/doroszewski/wylatywac;5520558.html

Zych, A. (2004). Paradygmat słowotwórczy jako jednostka badań konfrontatywnych. In P. Czerwiński \& H. Fontański (Eds.), Język rosyjski w konfrontacji z językami Europy w aspekcie lingwokulturoznawczym (pp. 129-140). Wydawnictwo Uniwersytetu Śląskiego.

\section{Bibliography (Transliteration)}

Berend, M. (2003). Aktywność słowotwórcza czasowników ruchu (opis gniazdowy). In M. Skarżyński (Ed.), Słowotwórstwo gniazdowe: Historia, metoda, zastosowania (pp. 100-106). Księgarnia Akademicka.

Brazauskene, E. M. (1991). Slovoobrazovatel'nyı̆ potentsial prefiksal'nykh glagolov sovremennogo russkogo iazyka [Summary of doctoral dissertation]. Akademiia nauk SSSR, Institut russkogo iazyka.

Buzashshiova, K. (1987). Vozmozhnosti i granitsy modelirovaniia na urovne slovoobrazovatel'nykh paradigm. In Sopostavitel'noe izuchenie slovoobrazovaniia slavianskikh iazykov (pp. 14-19). Nauka.

Buzássyová, K. (1974). Sémantická štruktúra slovenských deverbatív. Veda.

Doroszewski, W. (Ed.). (1958-1969). Słownik języka polskiego [SJPD] (Vols. 1-11). Wiedza Powszechna.

Greshchuk, V. V., Bachkur, R. O., Dzhochka, I. F., \& Poslavs'ka, N. M. (2007). Narysy z osnovotsentrychnoï deryvatolohii. Misto NV.

Horodens'ka, K. H. (Ed.), Vykhovanets', I. R., Zahnitko, A. P., \& Sokolova, S. O. (2017). Hramatyka suchasnoï ukraïns'koï literaturnö̈ movy: Morfolohiia. (2017). Vydavnychyı̆ dim Dmytra Buraho.

Hrinchenko, B. D. (1996). Slovar' ukraïns'koï movy [SUMH] (Vols. 1-4). Naukova dumka. 
IAroshenko, N. (2007). Statystychna formula slovotvirnoho hnizda v zistavnomu aspekti (na materiali rosiǔs'koï, ukraïns'koï, pol's'koï ta anhliǔs'koï mov). Linhvistychni studiï: Zb. nauk. prats', 15, 425-430.

Jochym-Kuszlikowa, L. (1982). Metoda analizy gniazdowej $w$ konfrontatywnych badaniach słowotwórstwa współczesnego języka polskiego i rosyjskiego (formacje odprzymiotnikowe). Wydawnictwo Naukowe WSP.

Karpiłowska, E. A. (2007). Gniazda słów jako językowy obraz świata: Perspektywy badań porównawczych. LingVaria, 2(2(4)), 27-41.

Klimenko, N. F. (1991). Slovoobrazovatel'nye gnezda slov kak ob"ekt tipologicheskogo izucheniia. In Aktual'nye problemy russkogo slovoobrazovaniia: Materialy VI resp. nauchn.-prakt. konf. Samarkand (pp. 81-83). [n.p.].

Klymenko, N. F., Peshchak, M. M., \& Savchenko, I. S. (1982). Formalizovani osnovy semantychnoï klasyfikatsiï leksyky. Naukova dumka.

Koriakowcewa, E. (Ed.). (2010). Aktualne problemy komparatystyki stowiańskiej: Teoria i metodologia badań lingwistycznych. Wydawnictwo Uniwersytetu Przyrodniczo-Humanistycznego.

Kovalyk, I. I. (1969). Porivnial'no-typolohichne vyvchennia slovotvirnykh struktur sporidnenykh mov. In Pytannia slovotvoru skhidnoslov'ians'kykh mov: Materialy mizhvuz. respubl. nauk. konf. (pp. 4-7). Naukova dumka.

Krongauz, M. A. (1998). Pristavki i glagoly v russkom iazyke: Semanticheskaia grammatika. Shkola "IAzyki russkoĭ kul'tury”.

Kushlyk, O. P. (2015). Slovotvirna paradyhmatyka pokhidnykh diiesliv v ukraïns'kiŭ movi. Kolo.

Malanowska-Statkiewicz, M. (2017). Potencjał słowotwórczy wybranych czasowników dźwiękonaśladowczych w języku czeskim i polskim. Slavica Wratislavensia, 165, 255-265. https://doi.org/10.19195/0137-1150.165.22

Manucharian, R. S. (1983). Slovoobrazovatel'naia paradigma i sopostavitel'no-tipologicheskiı̌ aspekt slovoobrazovaniia. In Russkiu iazyk: Voprosy teorii i metodiki: Sb. statě̆ (Vol. 2, pp. 5-15). Izdatel'stvo Erevanskogo universiteta.

Nagórko, A. (2007). Zarys gramatyki polskiej. Wydawnictwo Naukowe PWN. https://vdocuments.mx /nagorko-alicja-zarys-gramatyki-polskiej.html

Neshchimenko, G. P. (1983). O nekotorykh aspektakh sopostavitel'nogo izucheniia slavianskogo slovoobrazovaniia. In Sopostavitel'noe izuchenie grammatiki i leksiki russkogo iazyka s cheshskim i drugimi slavianskimi iazykami (pp. 30-51). Izdatel'stvo Moskovskogo universiteta.

Ohnheiser, I. (Ed.). (2003). Komparacja systemów i funkcjonowania współczesnych języków słowiańskich: Vol. 1. Słowotwórstwo/nominacja. Uniwersytet Opolski, Instytut Filologii Polskiej; Opolskie Towarzystwo Przyjaciół Nauk.

Rakhilina, E. V., \& Prokof'eva, I. A. (2004). Rodstvennye iazyki kak ob"ekt leksicheskoĭ tipologii: Russkie i pol'skie glagoly vrashcheniia. Voprosy iazykoznaniia, 2004(1), 60-78.

Sehin, L. V. (2019). Prefiksal'ni diieslova zi znachenniam “peremishchennia vhoru” v strukturi slovotvirnoï paradyhmy diieslova v ukraïns'kiŭ movi. Studia z Filologii Polskiej i Słowiańskiej, 54, Article 1735. https://doi.org/10.11649/sfps.1735 
Sehin, L. V. (2020). Typolohiia slovotvirnykh paradyhm prefiksal'nykh diiesliv zi znachenniam "peremishchennia vhoru" v pol's'kiŭ movi. Studia z Filologii Polskiej i Słowiańskiej, 55, Article 2021. https://doi.org/10.11649/sfps.2021

Skarżyński, M., Berend, M., Bondkowska, M., Burkacka, I., Jadacka, H., Olejniczak, M., \& Vogelgesang, T. (2004). Słownik gniazd słowotwórczych współczesnego języka ogólnopolskiego: Vol.3. Gniazda odczasownikowe [SGSWJO] (Pt. 1-2). Towarzystwo Wydawnicze "Historia Iagellonica".

Slovnyk ukraïns'koï movy [SUM] (Vols. 1-11). (1970-1980). Naukova dumka.

Sokolova, S. O. (2003). Prefiksal'nyı slovotvir diiesliv u suchasniu ukraïns'kiı movi. Naukova dumka.

Sopostavitel'noe slovoobrazovanie slavianskikh iazykov. (1987). Nauka.

Strekalova, Z. N. (1979). Morfologiia glagol'nogo vida v sovremennom pol'skom literaturnom iazyke. Nauka.

Valiukh, Z. O. (2013). Slovotvirna paradyhma iak ob'iekt zistavnoï typolohiï. Naukovyı visnyk kafedry IUNESKO Kyïvs'koho natsional'noho linhvistychnoho universytetu: Filolohiia, pedahohika, psykholohiia, 27, 6-10. http://nbuv.gov.ua/UJRN/Nvkyu_2013_27_3

Velykyı̆ tlumachnyı slovnyk suchasnoï ukraïns'koï movy [VTSSUM]. (2001). VTH "Perun”.

Velykyi zvedenyi orfohrafichnyi slovnyk suchasnoï ukraïns'koïleksyky [VZOSSUL]. (2003). VTF "Perun”.

Vykhovanets', I. R. (1988). Chastyny movy v semantyko-hramatychnomu aspekti. Naukova dumka.

Vylazyty. (n.d.). In Akademichnyi tlumachnyı̆ slovnyk ukraïns'koï movy. Retrieved September 13, 2021, from http://sum.in.ua/s/vylazyty

Wielki słownik języka polskiego [WSJP]. (n.d.). https://www.wsjp.pl

Wylatywać. (n.d.). In Słownik języka polskiego. Retrieved September 13, 2021, from https://sjp.pwn.pl /doroszewski/wylatywac;5520558.html

Zemskaia, E. A., Ermakova, O. P., \& Rudnik-Karvat, Z. (1993). Teoreticheskie problemy sopostavitel'nogo izucheniia slovoobrazovaniia slavianskikh iazykov (semantikofunktsional'nyı̆ aspekt). In Slavianskoe iazykoznanie: XI Mezhdunarodnyı̆ s"ezd slavistov: Doklady rossiǔskoŭ delegatsii: Sb. dokladov (pp. 248-263). Nauka.

Zych, A. (2004). Paradygmat słowotwórczy jako jednostka badań konfrontatywnych. In P. Czerwiński \& H. Fontański (Eds.), Język rosyjski w konfrontacji z językami Europy w aspekcie lingwokulturoznawczym (pp. 129-140). Wydawnictwo Uniwersytetu Śląskiego. 


\section{The Derivational Potential of Prefixed Verbs with the Meaning of 'Moving Upwards' in the Ukrainian and Polish Languages (Comparative and Typological Aspects)}

Summary

This article is devoted to the derivational potential of prefixed verbs with the meaning 'moving upwards' in the Ukrainian and Polish languages in comparative and typological aspects. The study identifies the main factors that affect the derivational behaviour of the verbs in focus, delineates the structural types of specific derivational paradigms according to the number of word-class blocks of the deverbatives, reconstructs a typical derivational paradigm of the verbs under study, pinpoints the derivational meanings which fill this paradigm, and determines the ways of realisation of derivational meaning. The study found that prefixed verbs have a significant derivational potential. Based on a comparative analysis of derivational paradigms, it was established how prefixed verbs with the meaning of 'moving upwards' in the Ukrainian and Polish languages realise their derivational potential according to the following parameters: (1) the word-formative potential of the same lexical-semantic group to generate derivatives which belong to various blocks; (2) the derivational meanings of a typical derivational paradigm realised by derivatives in each of the compared languages; (3) the statistical pattern of derivational paradigm; (4) the degree of correspondence of the derivative potential of equivalent root words in the studied group; (5) correlate sets of derivational formants which are involved in the realisation of derivational meanings in a typical derivational paradigm; (6) the ways of formation of deverbatives in each of the languages, which reveals both common features and differences between them. 


\title{
Potencjał słowotwórczy czasowników przedrostkowych o znaczeniu 'przemieszczać ku górze' w języku ukraińskim i polskim (aspekt porównawczy i typologiczny)
}

\author{
Streszczenie
}

Artykuł skupia się na potencjale słowotwórczym czasowników przedrostkowych o znaczeniu 'przemieszczać ku górze' w języku ukraińskim i polskim $\mathrm{w}$ aspekcie porównawczym i typologicznym. W toku badań ustalono główne czynniki wpływające na zachowanie słowotwórcze analizowanych czasowników, wyodrębniono typy strukturalne konkretnych paradygmatów słowotwórczych w zależności od liczby bloków części mowy, do jakich należą dewerbatywy, zrekonstruowano typowy paradygmat słowotwórczy analizowanych czasowników, wskazano znaczenia słowotwórcze, które wypełniają ten paradygmat, oraz określono sposoby realizacji znaczenia słowotwórczego. Badania wykazały, że czasowniki przedrostkowe mają znaczący potencjał słowotwórczy. $\mathrm{Na}$ podstawie analizy porównawczej paradygmatów słowotwórczych ustalono, w jaki sposób czasowniki przedrostkowe o znaczeniu 'przemieszczać ku górze’ w języku ukraińskim i polskim realizują swój potencjał słowotwórczy według następujących parametrów: (1) potencjał słowotwórczy tej samej grupy leksykalno-semantycznej do generowania derywatów należących do różnych bloków; (2) znaczenia słowotwórcze typowego paradygmatu derywacyjnego, realizowane przez derywaty w porównywanych językach; (3) statystyczny schemat paradygmatu derywacyjnego; (4) stopień zgodności potencjału słowotwórczego ekwiwalentów słów podstawowych w badanej grupie czasowników; (5) powiązane zbiory formantów derywacyjnych funkcjonujące w realizacji znaczeń w typowym paradygmacie słowotwórczym; (6) sposoby formowania dewerbatywów w porównywanych językach, ujawniające zarówno wspólne cechy, jak i różnice między nimi.

Keywords: derivational paradigm; specific and typical derivational paradigm; deverbatives; derivational meaning; structural type of derivational paradigm; ideal language type 
Słowa kluczowe: paradygmat słowotwórczy; konkretny i typowy paradygmat słowotwórczy; dewerbatywy; znaczenie słowotwórcze; strukturalny typ paradygmatu słowotwórczego; językowy typ idealny

Liubomyr V. Sehin, National University of Kyiv-Mohyla Academy, Kyiv, Ukraine ORCID: https://orcid.org/0000-0003-1966-0773

Correspondence: Lyubomyr137@gmail.com

The preparation of this article was self-financed by the author.

Competing interests: The author has declared that he has no competing interests.

Publication history: Received: 2020-05-20; Accepted: 2021-08-09; Published: 2021-12-20 